\title{
The Governmentality of Rural Household Waste Management Practices in Ala Ajagbusi, Nigeria
}

\author{
Saheed Adebayo Abdulwakeel * and Orjan Bartholdson \\ Department of Urban and Rural Development, Division of Rural Development, Swedish University of \\ Agricultural Sciences, Ultuna, 75007 Uppsala, Sweden; orjan.bartholdson@slu.se \\ * Correspondence: sdab0001@stud.slu.se; Tel.: +234-803-389-4733
}

Received: 9 May 2018; Accepted: 6 June 2018; Published: 8 June 2018

\begin{abstract}
There is a gap in the literature linking waste management practices to social theory. This paper attempts to bridge this gap through a study of waste management practices in Ala Ajagbusi village, Nigeria. The study explores how members of households in Ala Ajagbusi handle waste. The relevant themes of the empirical findings are categorized and linked to a social theory, Michel Foucault's governmentality. The aim was to investigate how members of the households handle and make sense of their waste management practices. This research adopts a qualitative approach and is inspired by phenomenology. These are the bedrocks upon which the data collection methods are chosen and the interview questions are informed accordingly. The results show that villagers collectively, every week in a rotational manner, sweep their households, dispose of, and burn waste in public spaces. Villagers walk some miles from their households before they can empty their waste receptacles. Sometimes waste management behaviours are adjusted to seasonal variations. The findings also show that the villagers have no engagement with the state and local government concerning waste management. The results are linked to social theory to understand the waste management behaviours of villagers in Ala Ajagbusi.
\end{abstract}

Keywords: waste; governmentality; household; moral codes; political technology

\section{Introduction}

There is a wide gap in the literature linking waste management practices to social theory. This paper attempts to bridge that gap through a study of waste management practices in Ala Ajagbusi village, Nigeria. There is significant empirical information on the waste situation, characteristics and waste management practices in Nigeria. In Nigeria, poor waste management practices have been associated with inadequate waste management awareness, inappropriate waste management attitude and inadequate basic waste management infrastructure such as incinerators, recycling plants, and high-tech landfill facilities (Ifegbesan 2010; Mansur 2015). Regarding inadequate waste awareness/education, the inappropriate management of the waste can be due to inadequate education about the environmental/economic advantages of a systematic waste management. For instance, the waste can be used as the source for production of energy, biofuel and biodiesel. So, education about the value of the waste and providing facilities are likely to motivate individuals to manage their waste in a proper manner (Hanifzadeh et al. 2017; Hanifzadeh et al. 2018). In a study of waste management practices in southwestern Nigeria, Ifegbesan (Ifegbesan 2010) submits that waste separation practices were very inappropriate amongst the informants interviewed. Adogu et al. (2015) conclude that the majority of the people interviewed in their study do not separate their waste before disposal. In Nigeria, the most common waste disposal practices are open dumping and burning, mainly along highways, within cities and open spaces (Ifegbesan 2010; Mansur 2015). (Mansur 2015) points out that 
these are unsustainable methods of disposal. Inappropriate waste management practices are understood to be linked to outbreaks of contagious diseases (Ifegbesan 2010; Mansur 2015; Adogu et al. 2015).

Inappropriate waste management is one of the social problems confronting the people of Nigeria. The problem has no geographical boundaries; in fact, the intensity of the issue in urban settlements is disheartening and calls for urgent attention. Paradoxically, it is often perceived that the urban dwellers enjoy a well-planned waste management service, but in reality it is not true. Urban waste management, as is shown in the abovementioned literature, fell short of general perception. It is a known fact that rural dwellers handle waste in the worst possible ways when compared to urban dwellers. The rural dwellers' experiences in waste handling are the focus of this paper and, importantly, it is connected with the theory of governmentality. In order to do this, Ala Ajagbusi rural village in Nigeria was chosen as a case study village because it is convenient to access.

In Ala Ajagbusi, villagers are increasingly trashing their surroundings, and recognition of this phenomenon has provoked this research. This research not only seeks to understand how the members of households have been handling waste, but also to identify the mentality of the government in waste handling experience through the lens of theory of governmentality. This explorative research does not seek to evaluate the sustainability or environmental impacts of waste management practices in Ala Ajagbusi rural village, but instead aims to understand how waste is being managed in the village with some attempt at linking this to social theory.

\subsection{Waste Composition in Nigeria}

Waste materials are viewed as valueless and useless materials that cannot be recycled for actual use (Abila and Kantola 2013). The sources of waste in Africa, including Nigeria, include industrial, sewage, agricultural, domestic or residential (household), municipal, process, institutional, medical and electronic waste (Bello et al. 2016). Plastic waste constitutes a significant percentage of waste in Nigeria. Many of these materials are often used as packaging of various commodities. Plastic waste poses a great threat to the environment as a result of zero waste management involvement by both packaging and commodities' producers; these entities are more interested in profit making than in managing waste (Abila and Kantola 2013). The majority of household waste in most cities in Africa is composed of biodegradable materials. In Imo State, Nigeria, household waste is mainly composed of food residue (Adogu et al. 2015). The waste composition in Nigeria has an implicit relationship with the income level of the members of the households and the types of houses in which they are living. In a household survey on waste composition and quantities in Abuja Nigeria, Ogwueleka (2013) posited that organic matter forms the highest percentage of waste components among all groups of income earners in the households investigated. The author states that there is a notable difference between household size and the amount of waste per capita generated in all income groups except the low-income earners. The result is similar to that of Monney et al. (2013), who found that waste per capita generated among high-income earners is higher compared to low-income earners in urban areas of Ghana; this is due to the higher purchasing power of high-income earners. Monney et al. (2013) state that inert materials (ashes, sand, etc.) are common among low-income earners who are living in unpaved surroundings and cannot afford stoves or cooking gas. Both studies suggest that there is an explicit relationship between the amount of waste generated and the level of household members' income.

\subsection{Study Site}

Ala Ajagbusi is a disputed rural village located in between Idanre local government and Akure North local government; both local governments are units of Ondo State and Ondo state is one of the federating units of the Federal Republic of Nigeria. The village is located $30 \mathrm{~km}$ southeast of Akure, the capital city of Ondo state. The village receives rainfall all year round, with an average maximum of $258 \mathrm{~mm}$ in the month of September and a minimum of $8 \mathrm{~mm}$ in the month of January. The average temperatures of the village vary during the year by $3.9^{\circ}$ Celsius (Ala Ajagbusi Climate Data 2017). 
The village has more than 500 households with over 6000 inhabitants ${ }^{1}$. A majority of the inhabitants are peasant cash crop farmers who mainly cultivate cocoa and palm trees but have a few fields cultivated for food crop production. Apart from farming, people engage in non-farm economic activities such as telecom accessories trading, mercantile, craftsmanship, and vocational jobs such as automobile repair, barbering, tailoring, hairdressing, welding, etc.

In addition, villagers engage in agricultural processing activities. The village has a periodic market that is held every five days and brings together several smaller villages. In addition, many educational, poultry, and fisheries businesses have emerged within the last two decades. Ala Ajagbusi is a strategic community for Akure indigenes (people who are known for cocoa cultivation in southwestern Nigeria; culturally, they are connected to the River Ala) because of its vast arable land. Migrants, who are mainly from nearby states, are predominantly found in the nonfarm and off-farm rural economic sectors because of Ala Ajagbusi's well-entrenched inheritance land tenure system. See Figure 1 for the location of Ala Ajagbusi village.

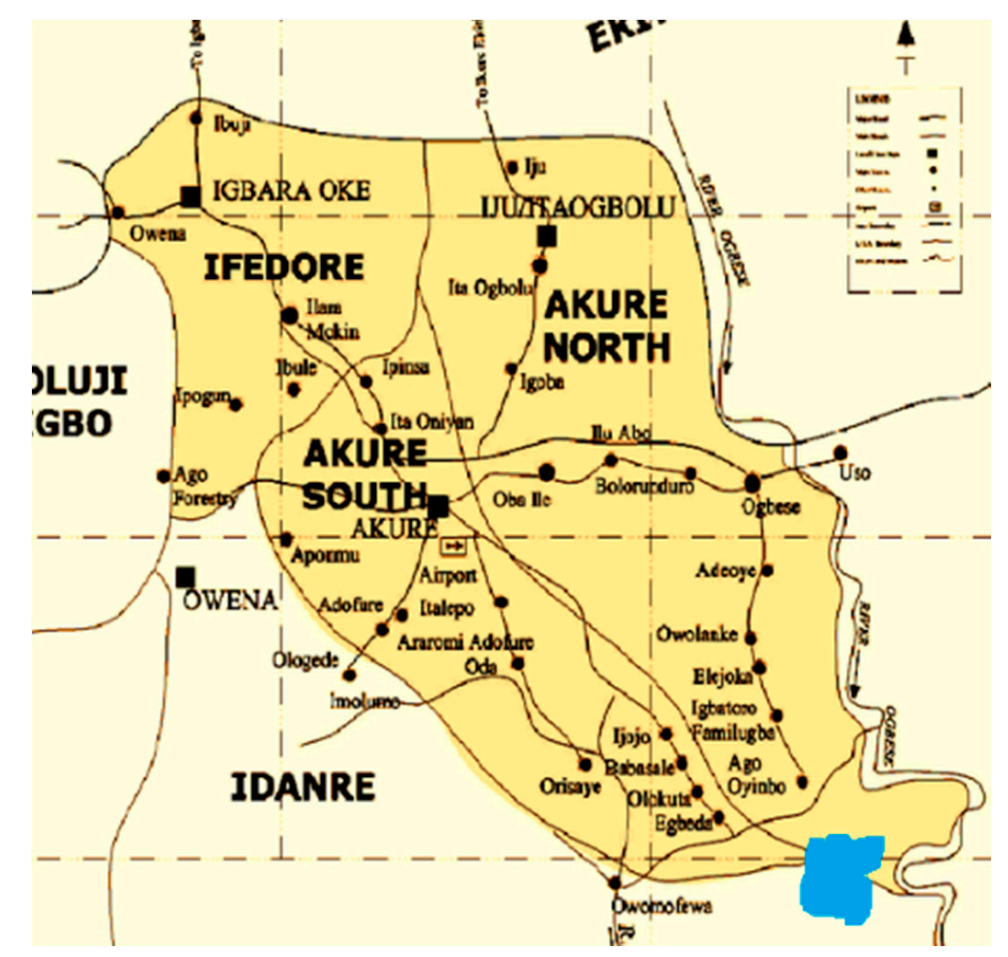

Figure 1. The political boundaries of Akure North and the location of Ala Ajagbusi (blue spot). Adapted from the work of Olamiju and Olujimi (Oluwadare and Julius 2011).

\subsection{Theoretical Framework}

In this subsection the objective is to lay down the theoretical framework we rely on to analyse the empirical findings in order to answer the research question. We seek to understand how the people of Ala Ajagbusi have been handling waste in relation to mentality of the government. For this purpose, we adapt Michel Foucault's concept of governmentality (Foucault 1991). What follows is a short description of this concept and how it serves as an analytical tool to analyse the empirical findings.

Foucault's concept of governmentality is focused on how people's behaviour is affected and framed by technologies of discipline, producing different subjectivities over time and over space

1 Personal observation, the observation was guided by Ala Ajagbusi aerial Google map, which was removed due to copyright issues. 
(Dean 2010). The governmentality concept encompasses how governmental techniques or political technologies and individual techniques shape, regulate, and order the behaviour of individuals or group of individuals in spite of sovereignty of these subjects (Amos 2010). The aspects of governmentality are twofold and are interrelated and inseparable (Miller and Rose 2008). These are rationalities of government (the reasoning about particular problems) and technologies of government (how rationalities are achieved) (Miller and Rose 2008). It is in the sense of rationalities and technologies that those who possess the mentality of government order, regulate, and shape the behaviour of their subjects to achieve or towards a specific end (Miller and Rose 2008). The subjectivities of the subjects, through the confluence of rationalities and technologies, seem to be self-governing or to have collective responsibility (Miller and Rose 2008).

Apart from the state administration "governmentality" also denotes self-control and even how households are organized and the members' behaviour are affected and framed (Lemke 2000). Foucault, in a metaphorical manner, opines that there are three fundamental types of government: government of oneself is about the morality, the government of family is about the economy and the government of the state is about politics (Dallegrave and Ceccim 2013). Foucault states that a person who wants to govern a state must know how to govern himself, his goods, and patrimony (Foucault 1991). Furthermore, government of oneself as morality or self-control is to say that individuals possess the mentality of the government through which such individuals shape and order their thoughts, body, and soul (Amos 2010).

$\mathrm{Li}$ (2007) opines that governmentality denotes an understanding that exercising power is not limited to the state, but also to individuals, groups of individuals, and civil societies that want to make a change through programs and interventions. For Li (2007), the exercise of government is not limited to the official state apparatus with its "diverse state agencies with competing visions, mandates and techniques"; "it also includes other actors from different sectors of society involved in different programs and interventions, or improvement schemes". Taking this notion into account, we explore the technologies put in place by individuals or groups of individuals and civil societies to understand how household waste management is handled in Ala Ajagbusi village, Nigeria.

\section{Method}

This research adopts a qualitative approach, which suits the objective of the research. The research analyses how villagers and civil societies in Ala Ajagbusi village handle waste through the lens of the concept of governmentality. Observations of indiscriminate waste management behaviour in the area create a need for the research. As stated above, the research is primarily done not to assess the sustainability of the waste management behaviour of the villagers, but to explore how they have been handling waste with the aim of linking it with the social theory. This research has been inspired by phenomenology as a research design, which is about actors' meaningfulness of a phenomenon, experience, and memories (Inglis and Thorpe 2012).

\subsection{Participants}

The participants were selected randomly in Ala Ajagbusi village, Nigeria. The focus was mainly on women, based on the fact that in an African context managing waste in a household is one of the domestic chores of a housewife (Kadfak 2011; Solomon 2011). There were also a few male participants. The random selection was done based on the researcher's discretion. The body language of the villagers was a great tool the researcher used to identify participants for interview. There were villagers whose attention was captured by the researcher being dressed differently. Everyone knows who is who in the village, knows how the villagers appear and knows how non-villagers navigate around; when villagers saw the researcher being a non-villager they were curious to know more. The researcher then capitalized on this scenario in order to select participants. This method is given credence by Burgess (Burgess 1984): the author opines that having basic interpersonal skills and procedures such as good appearance and good verbal and non-verbal communication play an important role in 
selecting participants. When undertaking research studies like this, one would expect the researcher to access the field through a gatekeeper for practical, safety, and ethical reasons, but in this case, a gatekeeper was not used because the researcher speaks the local language, is of western Nigerian origin, and is familiar with western Nigerian culture. This is similar to the position of Johl and Reganathan (Johl and Renganathan 2010), who opine that sometimes researchers have to negotiate their entry into the research field where environments are foreign to the researchers. It will be mandatory to use a gatekeeper where a researcher does not have legitimate and familiar access to the field, but otherwise the use of a gatekeeper is not mandatory, although it may be good practice to have one (Research and Enterprise Services, Newcastle University, Newcastle upon Tyne NE1 7RU, United Kingdom). In this study, the first author did not consider the use of a gatekeeper necessary, though this could not be said of the first author if the research study was undertaken in northern, eastern or southern Nigeria.

On many occasions when the motive of engagement had been explained, many villagers rejected the idea of being interviewed. Some of them did not give reasons for their actions, but there were a few who thought that the exercise was a government directive; hatred for the government formed the basis of their rejection, which is a function of the failure to meet expectations on the part of the government. In three cases, informants were selected in a snowballing method, as suggested by Creswell (Creswell 2014), in which the outcome of specific interviews led to the selection of further participants. In the end, 27 participants were selected. The sample size of 27 informants is $0.45 \%$ of approximately 6000 inhabitants in the study village; this is a bit fairer when compared to Boateng et al. (2016). The authors used 331 respondents out of the total population size of 279,282 , representing $0.12 \%$. Seventeen males and females participated in one-on-one in-depth interviews and 10 females participated in a focus group discussion. The participants were aged between 20 and 65 years old and were mainly migrants from neighbouring states. The participants were farmers, traditional chiefs, drivers, traders, school proprietors, and housewives. Table 1 provides brief information on the socioeconomic status of the participants.

Table 1. Participants' socioeconomic information.

\begin{tabular}{ccc}
\hline & Number of Participants & Representation in Total Sample (\%) \\
\hline Sex & 7 & 26 \\
Male & 20 & 74 \\
Female & & \\
Marital Status & 22 & 82 \\
Married & 2 & 7 \\
Single & 1 & 4 \\
Widow & 2 & 7 \\
Separated & & \\
Economic Activity & 4 & 14 \\
Farmer & 6 & 22 \\
Trader & 1 & 4 \\
Driver & 1 & 4 \\
Leader ${ }^{1}$ & 3 & 11 \\
Tailor & 1 & 4 \\
Teacher & 11 & 41 \\
Unemployed & 1 &
\end{tabular}

In Ala Ajagbusi village there are two traditional leaders, the Olu of Ala and Elefoson. This is because of the land dispute crisis in the village. The researcher only interviewed the Olu of Ala and forsook the idea of interviewing the second traditional chief since the research focus was not the conflict in the community and the researcher considered this a safety and ethical consideration. In Nigeria, traditional rulers have no constitutional power or responsibilities, but their subjects hold them in higher esteem as a result of their historical power before and during colonial times. The traditional leaders' 
power was eroded when Nigeria adopted a post-colonial constitution. In spite of this, the traditional chiefs perform civil functions such as managing matters relating to land disputes, theft, family discord and marriage disputes, as well as acting as a conduit for the government to reach people on governance matters, and maintaining peace within their domain. It is imperative to state that some of the traditional chiefs' judgments are held as precedent in the magistrate and lower court of law in Nigeria.

\subsection{Interviews}

The data collection used the qualitative methods of one-on-one interviews and focus group discussions (Creswell 2014). This was intended to explore villagers' waste handling experiences (Inglis and Thorpe 2012; Creswell 2014; Mason 2002). The interview questions were informed by the research themes: types and composition of waste, waste management practices, waste handling experiences and perceptions about waste. The interviews were inspired by phenomenology; the interviewees were allowed to narrate their experience as it appears to them and to construct meaning around their experiences (Inglis and Thorpe 2012; Creswell 2014). The interviews were conducted in March and April 2017. The interview questions were open-ended and not structured, but they were focused around the research questions, concepts, and themes. The researcher started by explaining the motive of the interview to the interviewee. Consequently, the interviewees would be asked to give background about themselves. A few interviewees requested anonymity and did not give their names. To begin with, the researcher asked; "How do you see waste in this village?" Sometimes the interviewee would be left to continue their narrative and the researcher paid attention without interruption, especially when the narrative conformed with the research themes. Sometimes when interviewees gave incomplete answers, the researcher asked follow-up questions to gather more detail such as "Who?", "How many of you?", "Who came up with the idea?", "When was that?", "What do you mean?", etc. Sometimes when the researcher felt the respondent could provide detail about other themes, or the narrative faltered, the researcher would ask "How do you take care of waste in this household?", "For how long have you been doing this?", "Are there any penalties for violators?", etc. The researcher remained unbiased, allowing participants to give their account as it made sense to them. There were cases of digressions, but the researcher was able to manage the situation through repetition of the questions and sometimes the researcher would remind the interviewee of the central notion of the interview.

A focus group discussion was conducted with 10 women whose primary occupation was as housewives. Three of them did not tell the researcher their names. The discussion was facilitated by the researcher. The discussion was open-ended but informed by the research questions, concepts, and themes. Both interviews and focus group discussions were conducted in the Yoruba language, which the first author speaks. The interviews were recorded in audio files. Each individual interview lasted for an average of $30 \mathrm{~min}$. The focus group discussion lasted for about one and a half hours. The audio files were later translated into English from Yoruba by the first author and divided into categories and themes according to the research questions. During the interview sessions and focus group discussion, the first author jotted relevant notes in a field diary and observed the body language of the participants. The discussion in the interviews and focus group discussion flowed well.

\subsection{Observation}

Observations of the village were undertaken throughout the empirical study period. The aim was to see how the village is composed, how the waste is being handled in the village, and to validate some of the interview findings. The observations were predetermined with other methods of data collection before the commencement of the study but did not follow any specific guidelines. Like the interview questions, the observations were guided by the research questions, theoretical framework, research approach, and the focus of the study. The outcomes of the interviews sometimes suggested the need to observe a specific situation and there were also scenarios where outcomes of an observation occasioned an in-depth follow-up interview with an informant. 
The first author observed the structure of the houses, dumping sites, the demarcation of spaces, i.e., residential, businesses, common spaces, market, state agencies and others. The market has many open stalls where marketers trade agricultural produce, household items, food, and men's and women's clothing. Overall, observations included the waste hill, waste burning sites, demarcated lands, spaces under the power lines, waste management at the market and a host of others. Whenever an observation was made, the outcomes would be quickly recorded and notes made about its connection to the research focus.

\subsection{Data Analysis}

The data analysis process was inductive, i.e., generating theory from particular to general contexts through interpretations of the meaning of the data (Creswell 2014). We described, reported, analysed and interpreted the outcome of the fieldwork. Description was theory-laden, not just description; description through the lens of concepts brings about inductively generated theory from the data (Silverman 2015). When transcribing audio from interviews and the focus group discussion, the focus was on extracting relevant data for the interview themes, research questions, research problem, and the theoretical framework. All these, consequently, formed categories that were manually devised. After the transcription, the data were repeatedly read in order to ensure the analysis was grounded in the empirical material. Analytical questions were continually asked and reflection was done considering the study themes, categories and research question. The data analysis was done manually rather than with any qualitative data analysis software. The manual data analysis method used in this research is in line with the "three steps" analysis model for data interpretation, as suggested by Creswell (Creswell 2009); we structured the materials, connected to themes, and devised categories in relation to the theoretical or conceptual framework.

\section{Findings}

\subsection{Background Information}

Ala Ajagbusi village is one of the administrative units of Ondo State and the state is one of the federating units of the federal republic of Nigeria. The state has a sanitation law that compels everyone living within its geographical location to stay at home between the hours of 7:00 a.m. and 10:00 a.m. on the last Saturday of every month. On this day no one is expected to be roaming about; instead every member of the household is expected to collectively clean their neighbourhoods, empty drainage, gather waste in a waste bin or sack or bowl and help the evacuation truck drivers to collect waste. The local government is expected to send sanitation officers to enforce sanitation law and prosecute those who may disregard the law as well as making evacuation trucks available so as to transport the waste to the local government-designated dumping site. In addition, on a daily basis private waste management companies are saddled with the responsibilities of collecting waste and transporting it to the designated dumping site. These private waste management companies do not have rural settlements as their operational domain; they only focus on urban settlements. Hence, rural settlements are reliant on the government-run monthly sanitation programme to get rid of waste. Unfortunately, in Ala Ajagbusi the villagers do not observe the monthly waste management exercise due to the land dispute crisis between the two local governments wrestling over authority in the village.

In Ala Ajagbusi village there are civil society organisations that engage in waste management: the National Union of Roads Transport Workers (NURTW) and the Market Women Association (MWA). The NURTW is a reputable trade union in Nigeria. The union has a very formidable structure that ranges from unit to federal. The structure is somewhat similar to the Nigerian political division. The NURTW has several units of the division that are subjected to the branches' division directive. The delineation of units and branches is vague and is a function of state executives' whims and caprices. The interlinkages of units and branches form the state division, which is led by a chairman, 
while that of the state forms the federal division that is led by a president. The NURTW, as part of its mandate, provides welfare benefits for its members. The union officials mount road blocks to collect subscriptions from its members, sometimes by force. The NURTW in Ala Ajagbusi is one of the units controlled by a specific branch.

The Market Women Association (MWA) is a well-known civil society organisation in Nigeria. It has an administrative structure similar to that of NURTW. As part of its mission, it looks after the welfare of its members, guarantees market access, collaborates with the government to roll out empowerment programmes for market women, disseminates information of many kinds i.e., immunization/vaccination, voters' registration, voting, etc., and guarantees financial access to its members, amongst other tasks.

In the rest of this section the focus is on empirical findings regarding the waste management handling experience in Ala Ajagbusi village. It begins with a description of the dwellings to draw a picture of how the village is composed; subsequently, we present a narrative of the land dispute crisis between Idanre and Akure North local government in the village (both are municipals). The focus is on features of the waste infrastructure; the waste handling experiences, structures involved in waste handling, waste composition and the actors involved; the land owners and the dumping sites, the National Union Road Transport Workers (NURTW), and the Market Woman Association (MWA).

\subsection{The Dwellings}

In Ala Ajagbusi village houses have four or six rooms each. Each house has a single corridor or passage that is common to all inhabitants and through which each family accesses its rooms. In some of the households there are two or three families living together, although in others there might be a single family or an extended family. The houses have detached kitchens and bathrooms. In most cases, the kitchens are close to the households' waste storage space, where waste is stored before being burnt or left in the bush. The kitchens have roofs and are partly covered at the sides, sometimes without doors and ventilation windows. Each member of the household has their own cooking device made from stone within the kitchen. In some houses cooking facilities are located in front of the house. Firewood is the main source of cooking energy.

The majority of the bathrooms have no roof covers, no doors, and have low walls. Members of the households shield themselves from passers-by with fabric while taking showers, yet the individual's feet and heads are not covered. The majority of households have no toilet. Informant M4 stated that: "this is a dirt-ridden village: as you can see, there is dirt all over the place. You would hardly count 10 households with a toilet". Lack of toilets in houses is a common phenomenon in the village. Some of them have buckets at the back of their houses where they defecate; some defecate in the bush, while others still answer the call of nature in an open space under the power lines before dawn every day. Villagers expressed their worries about these conditions and they are concerned about the risk of contracting diseases. Informant M6 narrated his experience and stated, "That power line (pointing to its direction) especially before dawn, people often defecate under it. They line up and some of them are not shy of their behaviour, they send me greetings when I am on my way to the mosque. We are worried about this behaviour because we don't want cholera. The only police station in this village has no toilet; any time a suspect has to answer the call of nature, the suspect would be led by a constable to the power line, where the suspect would empty his or her bowels."

See Figure 2 for an image of a dwelling in Ala Ajagbusi.

\subsection{The Disputed Village}

Ala Ajagbusi is a disputed village; the village is located in between the boundary of Idanre local government and Akure North local government. The village has two leaders, one representing Idanre and the other Akure North. The Olu of Ala is representing Akure North, while Elefonson is representing Idanre (both are traditional titles). The police station, which is one of the four government institutions apart from the two primary schools and one secondary school in the village, was built 
after the year 2000 land dispute crisis between the Olu of Ala and Elefoson parties that claimed several lives. Many villagers submit that the poor village arrangement for waste management is a function of the land dispute crisis in the village. Because of this, they are confused about which party they should address concerning village waste management arrangements. Informant M5 said that "Literally, this is not our responsibility, but we take it on us because of the lack of government presence and the fact that this village is a disputed area between the local government of Idanre and Akure North. This makes village arrangements so difficult. The questions are, who gives orders and where do we report to? Is it the first chief or the second chief? So we are at a crossroads."

Furthermore, the lack of development projects in the village has been attributed by the villagers to the land dispute crisis between the Olu of Ala and Elefonson's parties. Each party opposes the development projects proposed by the opposing party. Elefonson's party often works against any project from Akure North, while Olu of Ala's party do the same for any project initiated by Idanre. Informant W10 in the village had this to say: "There are two leaders in this village. Despite the big size of this village, the polarization of the leadership has done more harm to this village by blocking several development projects." Each party engages in animosity because of fear of hegemony by either opposing parties, and the power play is so intense that it reduces the influence of either party in the village. Informant M6 said that "During the just concluded administration, a market project was allocated to Ala Ajagbusi from the state government through Akure North local government. The contractor was frustrated by Elefonson's party and the project was abandoned. All the construction materials already on the site were stolen by the villagers." This is to say that there is a strong nexus between peace and development. A society without peaceful co-existence cannot attain a reasonable level of development.

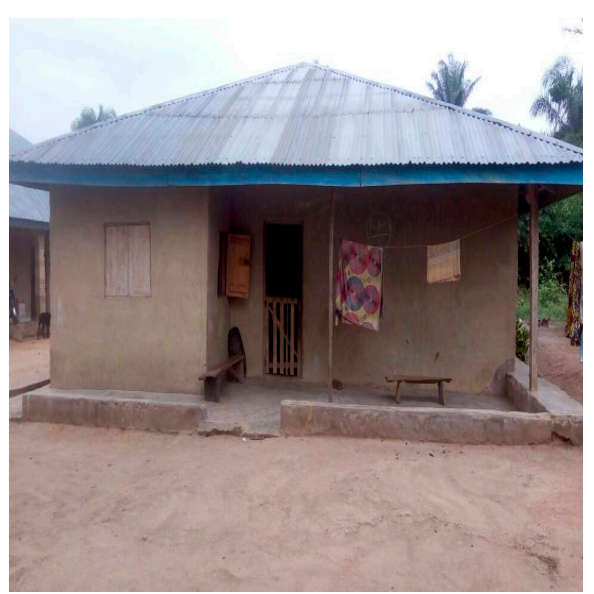

(a)

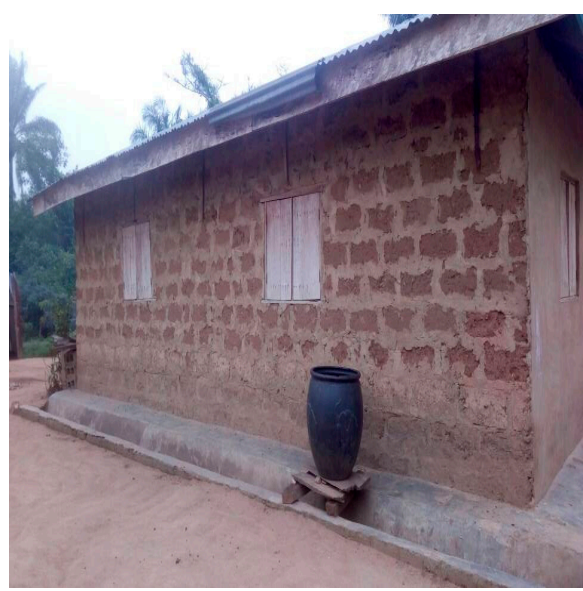

(b)

Figure 2. The dwelling (a) The front view of a house in Ala Ajagbusi; (b) the side view of a house in Ala Ajagbusi.

\subsection{Waste Composition in Ala Ajagbusi}

The understanding of waste by the villagers in Ala Ajagbusi is similar to the results of other waste management studies. The informants regarded waste as something that is useless and that should be kept away from the dwellings; "Waste is something one should not live with, is it possible to buy a loaf of bread and keep its plastic packaging in my room? It should be discarded because it is useless" (Focus group discussion, March 2017). However, during the focus group discussion some villagers argued that there are plastic containers that could be reused to bottle water, kerosene, and palm oil. Some said that chaffs from maize and palm kernel are often reused as energy for cooking; "Any time we buy something packaged in a plastic container, we reuse it to bottle our palm oil, kerosene, and water until we conclude that it is no longer useful. We don't discard chaffs from palm kernel and maize because we use it as cooking energy" (Focus group discussion, March 2017). Apparently, there is some waste that is being 
discarded immediately, whilst some waste is reused and discarded later. The chaffs from maize and palm kernel are usually classified as agricultural waste, but are classified as household waste in this study. In front of a few houses in the village there are big containers where some villagers cook palm kernels with the objective of extracting palm oil. After extracting palm oil, the chaffs become an energy resource that is used for cooking in the household in addition to firewood.

The waste composition in Ala Ajagbusi includes plastic materials, metallic materials, and organic materials; "The household waste consists of food and non-food plastic packaging, plastic containers, paper containers, paper cartons, emptied water sachets, organic materials (yam peel, cassava peel, plantain peel, vegetable remnants, chaffs from maize, chaffs from palm kernel, and animal faeces), metal bottles and inert materials (sand, ashes, and charcoal)" (Focus group discussion, March 2017). Some of the households' waste sacks, waste bowls, and small waste heaps are mostly composed of plastic materials of various types with larger amounts of inert materials (sand, charcoal, and ashes). Plastic materials are frequent among the waste types in the village and this has been linked to the increasing presence of urban merchants in the village, whilst the presence of inert materials in the waste composition village is linked to the increasing use of firewood as energy.

See Figure 3 for an image of waste composition in Ala Ajagbusi rural village, Nigeria.

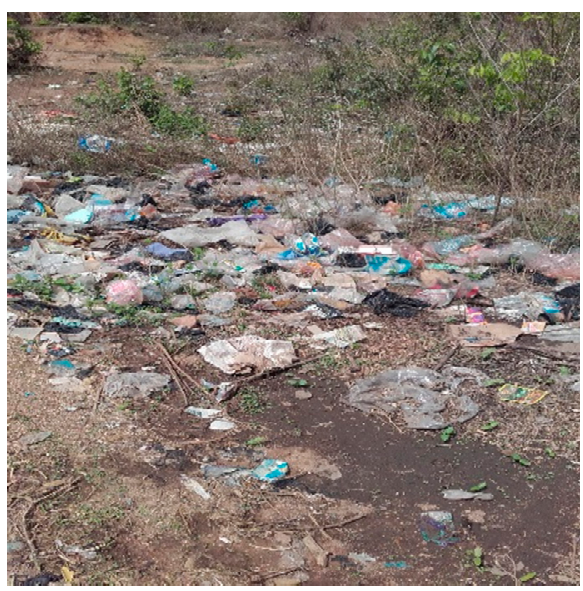

(a)

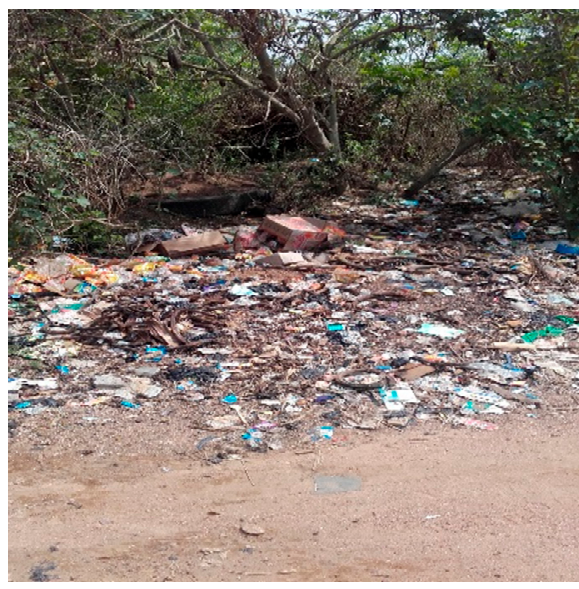

(b)

Figure 3. (a) Illegal dumping site showing waste composition; (b) another dumping site depicting waste composition.

\subsection{Waste Handling in Ala Ajagbusi}

The narratives of the villagers regarding the way the waste is being handled were broadly similar. All members of the households generate waste on a daily basis as they fulfil their needs. In a household, there is a division between personal space and common space. The personal space usually consists of private rooms, while common spaces are the passage or corridor, the front, the back and the two sides of the house. During the day, the common spaces are littered with dirt by the members of the household; this is usually swept up the next morning before dawn. Members of the households sweep each personal space individually and common spaces are usually swept collectively. Both spaces are swept in relation to notions of cleanliness and dirt. The wives in the families living in a household agree on terms to sweep the commons on a weekly basis, often in a rotational manner. Informant W9 stated that: "we are more than one family living under a single roof; each family is responsible for cleaning the surroundings for one week until the responsibility passes around, and each family is responsible for cleaning their own room every morning."

"In most households, except a household where there is a single family, the sweeping of the surroundings is done by all the families living in such a household in a rotational manner on a weekly basis. Although there are no penalties for a housewife who fails to adhere to the institutional arrangement of sweeping, she will be tagged 
as a bad housewife. Those who adhere see themselves as upholders of morality. Children and their mother sweep the surroundings of the house in a single-family household, each with a designated portion to sweep every day" (Focus group discussion, March 2017). "I am the owner of my house, my children and I are responsible for the sweeping of the house; each has his or her own portion to clean every day" (Interview with Informant W8, March 2017).

The practices of littering the "commons" (spaces shared by those living in a specific house) with trash during the day and getting it swept before dawn through a socially organized arrangement is necessitated by a lack of waste bins in the commons. This is also similar in public spaces, i.e., streets, markets, viewing centres, and religious centres. In the village, there are no waste bins on the streets, in the markets or other public spaces; thus, villagers throw trash indiscriminately. When the generated waste is being swept up, the waste is often stored unseparated in a sack, bag or bowl before being burnt or emptied into the bush, under the power line or into the street side drainage channel. Each family has its own waste sack and different methods for disposing of waste; "We pack the household waste in a sack unsorted and take it to the carpark there [using her finger to point towards the direction of ther carpark]; besides this carpark there is a wide waterway where we empty the waste, especially during the rainy season, with the expectation that the running water will take it down the stream" (Interview with Informant W2, March 2017). See Figure 4.

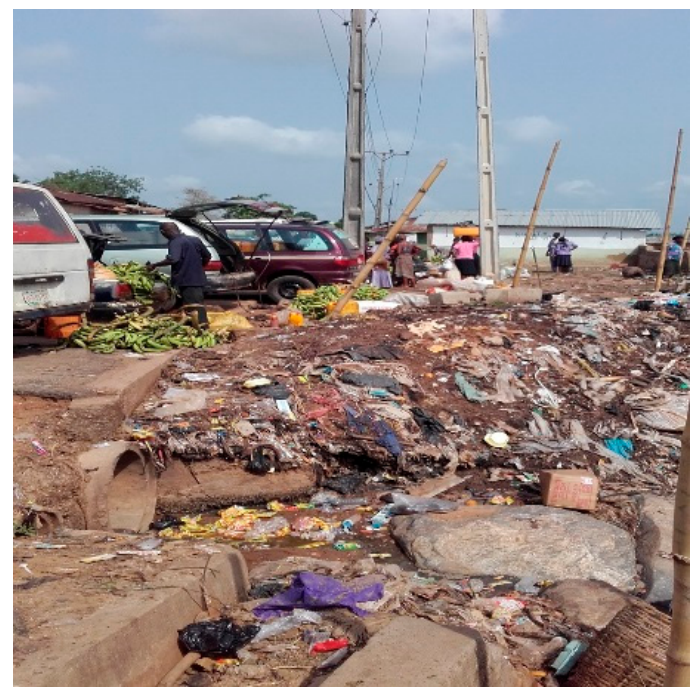

Figure 4. Showing the trashed waterway beside the carpark.

In another observed case, the waste would be put beside the drainage in front of the house, where it would be either burnt or emptied into the drainage. It could also be left at the back of the house, where it would be burnt. Informant W10 stated: "At daybreak each household in this street sweeps their surroundings and gathers the waste generated near the water drainage from where it would be burnt, emptied into the drainage or emptied into the bush." This is common practice in the village. This is so because of a lack of waste management infrastructure in the village; every villager is left to decide on their own how to handle waste.

\subsection{Structure in Waste Handling}

In a tropical climate, the seasons are divided into dry and wet (rainy). Ala Ajagbusi village is located in a tropical environment, thus the waste handling in the village has been structured in relation to the two seasons, dry and rainy. The villagers' everyday actions concerning waste management are adjusted to seasonal variations in the weather. This demonstrates a structuring of waste management actions. In the dry season, the common practice of waste disposal is burning, whilst in the wet or rainy season the waste disposal practice is dumping in an open space or into drainage channels. 
Informant W1 states that "We always keep the trash beside the waterway in front of the house; when rain starts the dirt is pushed down the waterway. Meanwhile, we burn our waste during the dry season." Informant W9 states that: "During the rainy season we empty our trash sack into the drainage channels and sometimes we empty it in an open space. In the dry season we burn it and members of the households that are very close to the dumping sites (under the power line and other illegal dumping sites) arrange amongst themselves to burn the waste during the dry season."

\subsection{The Land Owners and Dumping Site}

The common waste disposal practice in Ala Ajagbusi, if not burnt or emptied into the drainage channels, is dumping in an open space. In most cases the owners of the land where villagers dump their waste are living far away from their land. When they see that their land has been turned into a dumping site they get into conflict with those who are living close to the land. The practice becomes a point of conflict between the landowners and the villagers. "The land owners where we empty our trash bags are always in conflict with us and it always causes trouble," states Informant W4. The constant conflict between the landowners and the villagers, coupled with other factors, has forced the villagers to empty their waste bags under the power line and inside bushes. Informant W6 states that "The constant conflict between us [members of the households] and the landowners, the increased population, and the increased development of open lands have forced us to dump our waste under the power line." When asked about the rationale behind using the space under the power line as a place for waste dumping, the response was that the space does not belong to anyone. Therefore, the villagers see this place as a public space to which no one can claim ownership.

The villagers in Ala Ajagbusi freely trash the space under the power line. The power line and its surrounding is the property of the state and the space is not primarily available for any activities by other actors. Under the power line, there are signposts conveying safety messages to the villagers regarding the danger of the power line, but despite the safety warnings, the villagers freely dispose of their trash in the space because no one could stop them from such activity. Unfortunately, the law enforcement officers who are expected to enforce this often themselves lead suspects under the power line to defecate.

There are some areas of land where the owners have erected bamboo perimeter fencing to indicate the boundaries. In between the bamboo poles there are ropes lines and in between the ropes lines there are pieces of red fabric tied in knots, see Figure 5. This is done by the landowners; the objective is to tell the villagers not to trash the land with waste. If they do, the red fabric signals that such persons would be attacked violently. Many of the landowners employ this strategy to stop villagers from converting their lands to dumping sites.

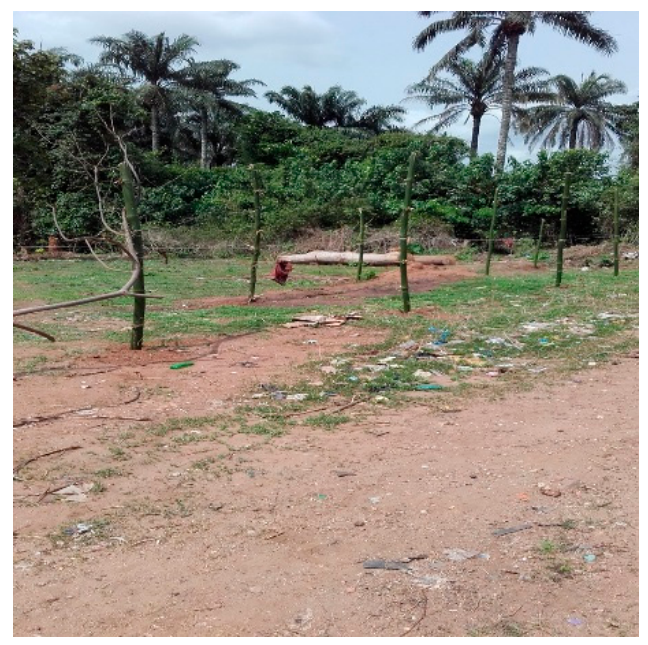

Figure 5. A bamboo and knotted fabric line perimeter fence. 
All the dumping sites in the village are illegal. There is no specific waste management arrangement prescribed by the government or the village administration. The villagers expressed their feelings regarding the failure on the part of the government; they do not see waste as the only problem in the village, but also the lack of water, electricity, and roads. The villagers make numerous demands on the government. Informant W10 stated that "We need roads, electricity, and water; the politicians promise us all these-especially during election campaigns — but do not live up to their promises."

\subsection{The Monthly Sanitation}

Informant W4 stated that: "The state government sanitation law compels everyone to stay at home between 7:00 AM and 10:00 AM every last Saturday of the month. During this period each household cleans their surroundings, empties the drainage and jointly burns the waste under the power line. In the case of the city, anyone who fails to comply would be arrested and prosecuted." In reality this law is not practiced in Ala Ajagbusi. No sanitation officer on the ground will enforce the law, there are no evacuation trucks, and villagers go about their daily business until village leaders encourage them to observe the hours for their own good even if no sanitation officer is available. Despite this, only a few villagers observe it; "Our expectation was that the local government would be here to enforce the sanitation law, but the reality is that we don't see them. Rather, women leaders and the local chiefs always encourage us to observe the stay at home hours for our own good" (Interview with Informant M1, March 2017).

The local government is responsible for assigning sanitation officers to various districts and for providing evacuation trucks, and the villagers have attributed the non-implementation of the sanitation law to the land dispute crisis between the two local governments (Idanre and Akure North) in the village. The two local governments that lay claim to the village find it difficult to perform waste management functions for fear of escalating the crisis. Informant W9 states: "the dispute in this village between Idanre local government and Akure North local government makes sanitation law implementation impossible."

Lack of toilets in houses in the village is attributed by the villagers to a lack of enforcement of the sanitation law. There are no officers to arrest and prosecute violators, especially those who are defecating in buckets at the back of their houses. Informant W8 states that "we would be happy if the sanitation program could be extended to this village, this is because there are houses without toilets; some use bucket toilets and this is not healthy. These people could be arrested and prosecuted and it would serve as deterrent to others." This shows that the unhealthy behaviour of some villagers is linked to a lack of sanitation programme in the village.

The villagers indicated willingness to get rid of the waste. This was suggested by their body language and by the statement of many that villagers show readiness to pay private investors to come in and provide waste management services, i.e., provisioning of legal dumping sites, evacuation trucks, waste bins, and other infrastructure. This and the call for strict implementation of the monthly sanitation programme will help villagers to improve on their waste management behaviour.

\subsection{The NURTW}

"The dumping site besides the carpark has become a major concern; if not for the concerted efforts of the NURTW, the dumping site would have turned into a death trap" (Interview with informant W2, March 2017). NURTW is a trade union with a mandate to look after the welfare of its members. NURTW Ala unit is involved in waste management in order to fulfil its members' mandate. The NURTW Ala unit has an office close to one of the dumping spaces in the village (see Figure 6); therefore, it becomes imperative for the trade union to stop villagers from trashing the space, and to reduce waste in the space to reduce the risk of spreading diseases. 


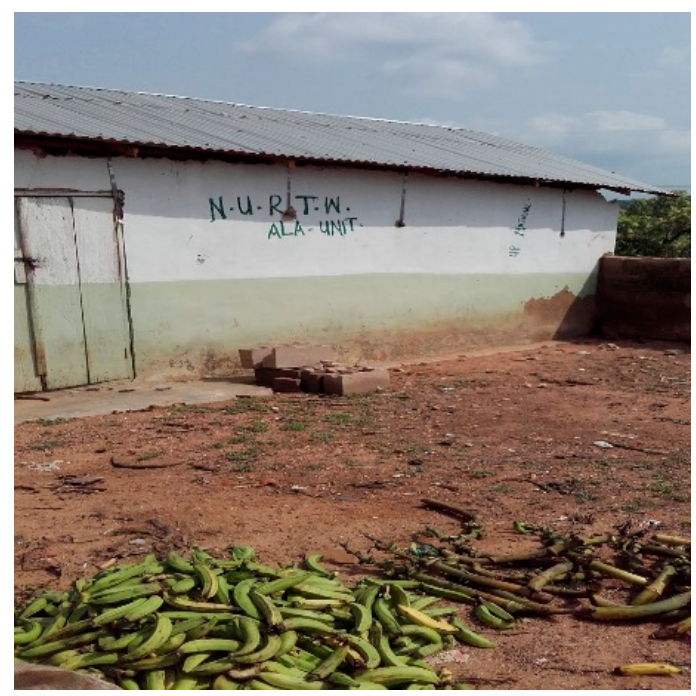

Figure 6. This is NURTW Ala Unit's Office.

Concerning the dumping site beside the carpark, one of the informants acknowledged that this waterway had become a dumping site for the villagers for decades due to the lack of a waste management structure in the village. "Many bring their household waste and empty it into the waterway, and during the market day the plantain sellers litter the side of the waterway with waste. On the market days, the waste from the bunches of plantains is always left beside the waterway, constituting an environmental nuisance and making movement difficult" (Interview with informant M5, March 2017).

As a result of this practice, the carpark and the nearby market have been experiencing recurring flooding for years. The union often burns the waste as part of its efforts to reduce the waste build-up. Informant M5 states: "We not only burn the waste during the dry season but we also push it down the stream during the rainy season. Most times when we burn the waste there are households that complain about the smoke emanating from the burning." During the market days, the marketers are allowed by the union to leave the plantain stalks in a small space near the waterway following the bamboo line erected around the waterway for such a purpose. The union takes care of the plantain stalks by hiring someone who will pack and dump it in the bush. The union further delegates a person who monitors marketers for compliance during the market days; "As a union, we don't have the power to enforce the law; sometimes we contribute money and ask some Fulani (a largely nomadic tribe mainly in the Sahara/Sahelian Africa) to pack the waste, especially the waste on the road beside the waterway. The delegate, Haruna, monitors people on every market day to ensure compliance" (Interview with informant M5, March 2017).

Regarding whose responsibility it is to reduce the waste dumped beside the waterway, one of the informants stated that the responsibility is vested in the local government and not in the villagers. However, because of the absence of local government, the informant said that the union has taken up the responsibility of reducing waste in the waterway because of its own interest. The union office is located very close to the waterway and some of the staff eat inside the union office; therefore, it was described as a necessity for them to reduce the waste in order not to contract diseases. Informant M5 states: "This place [pointing to a hill of waste in the wide waterway] is the responsibility of the local authority to manage, but we don't see the local authority officers and this is where we stay, this is our carpark. We are clearing the waste in order to escape the possibilities of contracting diseases. This is very close to the union office; we eat and we have our meetings here. Therefore, we have to do that for fear of diseases."

As part of the NURTW's strategy to manage waste in the waterway, informant M5 states that the union engages each member every day to be at the carpark before dawn; the delegate stays in his car and when he notices any villager attempting to dump waste, the delegate puts on his vehicle's headlamps to light up the area. If a culprit is discovered, he/she runs away for fear of arrest. This strategy has forced some of the villagers to empty their waste under the power line. 


\subsection{The Market Women Association}

Unlike in the city, markets in Ala Ajagbusi are not held on daily basis, but periodically. The market days are often at five-day intervals. On the market day, the market waste situation was observed; there was waste littering the ground, there were children pushing the remnants of plantain with wheelbarrows, and villagers were engaged in buying and selling. Many marketers come from different villages to engage in marketing activities. Marketers generate various types of waste such as plastic waste, paper waste, and agricultural waste. The common practice among marketers is to leave the waste in the market until the subsequent market day. When the marketers sweep their stalls before they start sales; "On the market day the environment is littered with paper, plastic bags, and other sorts of waste. These are left until another market day before being swept, unless surface runoff has already moved it down the stream. On every market day, before each marketer starts sales, each has to clean up her stall and its surroundings" (Interview with informant M11, March 2017).

Marketers take the sweeping of their stalls very seriously because of an associated cultural belief: the fear of not making a profit if the stalls are not swept forces them to sweep their stalls. Otherwise, many of them are not really ready to sweep their stalls before marketing activities. In this context, there is a nexus between dirtiness and economic losses on the one hand, and a connection between cleanliness and profits on the other hand. Therefore, in this case, we can rightly say that cultural beliefs produce sweeping behaviour among the marketers.

The Market Women Association, through its leadership, hires Fulani (see Figure 7) and some children to manage the waste generated on the market day. When the generated waste is being swept up by the marketers, the engaged Fulani and the children move around the market to pack the waste and empty it into a faraway bush or under the power line.

"The waste generated before, during and after the market day is often managed by the Market Women Association by hiring Fulani. The Fulani usually packs waste and empties it in the far distance, especially bushes along the highway or under the power line" (Interview with informant W11, March 2017). On a non-market day there were two Fulani boys emptying one of the drainage channels along an unpaved road that passes through the market. The Market Women Association hired the two boys to clear the drainage in preparation for heavy rain in the second quarter of the year in order to prevent flash flooding.

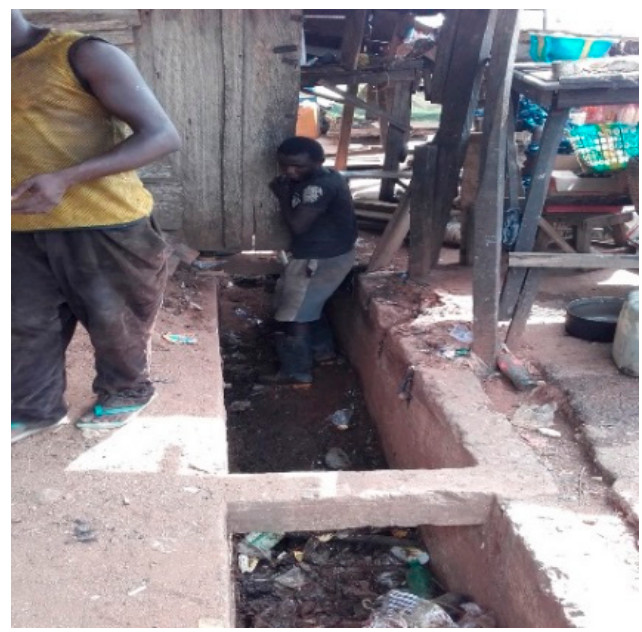

Figure 7. The hired Fulani.

\section{Discussion/Analysis}

In this section, we present a discussion and analysis of some of the empirical findings. In doing so, the concept of governmentality, described in Section 1, is applied inductively to generate a theory from the empirical findings. The result is compared with the outcomes of other studies. 


\subsection{Government of Oneself}

As stated in Section 1, Michel Foucault's concept of governmentality includes the government of oneself, deploying technologies of discipline likened to morality to shape or order the behaviours of oneself. Applying the notion of morality as posited by Michel Foucault implies that actors produce certain behaviours based on moral codes or self-control. In this sense, there are actors who exercise moral codes as technologies or mechanisms to shape their behaviour. The technology of discipline is often a product of rationalities of government, and convergence of rationalities and technologies bring about practices of government.

In the context of Ala Ajagbusi village, members of the households socially organized themselves into an informal institutional arrangement to get rid of waste in the household every morning before dawn. Each family sweeps all spaces in a household on a weekly basis in a rotational manner. The moral codes here seem to be "thou shall wake up every morning", "thou shall sweep the household", "thou shall sweep every morning for a week", and "thou shall not keep waste in your room". For instance, one of the informants asked the rhetorical question "is it possible to buy a loaf of bread and keep its plastic packaging in my room?" The informant was asking the question not for the interviewer to answer, but to reiterate the embedded immorality in keeping such packaging. This is to say, waste management behaviour is being adjusted by morality. We argue that the fear of contracting diseases, as stated by informants, also influences sweeping behaviour among the villagers.

In the context of waste management practices, one could argue that the state or local administration influences waste management behaviour because it often devises laws that come with a penalty/penalties to govern waste management behaviour. In the context of Ala Ajagbusi, no state or local apparatuses mandate waste handling, which has been attributed to the land dispute crisis in the village. By implication, it denotes that the absence of guidelines on waste handling positions villagers as non-violators irrespective of their waste-handling methods. Therefore, we argue that the villagers' waste sweeping behaviour is being shaped by what we call "hybrid" technologies; technologies of moral codes and the fear of not wanting to contract diseases. Still on the moral codes, the penalty of being labelled a bad housewife is an informal social institution relating to responsibilities for handling waste among the members of the households and also shapes sweeping behaviours. In this sense, the moral code is "thou shall not be tagged as a bad housewife". In this context, the rationality is to get rid of the waste, driven by both moral codes and the need for healthy living, which we have termed "hybrid" technologies. The essential thing here is that the practise of government is being invoked among the villagers as a result of the convergence of rationalities and technologies.

The term "hybrid" technologies stated above is akin to another study of governmentality in pro-environmental behaviour change (Dilley 2012). Dilley (2012) finds, in an analysis of the Energy Saving Trust's (EST) document, that EST appears to blend a moral code, "thou shall switch off the light," with a form of environmental and financial ethics. The similarity is seen in the behavioural perspectives, but differs case by case slightly in terms of drivers. In the case of energy consumption (Dilley 2012), the governing self or government of oneself is being driven by moral/ethical and financial technologies or mechanisms, which the author labels "hybrid" technologies. In this case, the rationality is to reduce energy consumption and the technology used to fulfil the rationality is a hybrid technology: moral/ethical and financial. In the case of waste management in Ala Ajagbusi, the technology used to fulfil the rationality is also a "hybrid" of moral and health. The difference is the composition of the "hybrid" drivers of behaviour; in energy consumption the drivers include economic, while healthy living is one of the drivers of behaviour in the waste management case. In both cases, morality is identified as a driver of behaviour. The important thing between the two cases is the convergence of rationalities and technologies that produce government practise.

What appears to be in contrast to the villagers' social control argument above is that, beyond their households, the villagers fail to uphold the virtue of morality when disposing of their waste in public spaces. This is being attributed to the lack of state order concerning waste handling, caused by the land dispute crisis in the village. Villagers dispose of waste indiscriminately. They fail to align with 
the advice from the village chief and MWA concerning waste handling in the public spaces. It is imperative to point out here that the contradiction in waste management behaviour within households and beyond households is an indication of the fact that the government of oneself and that of the state complement one another. In that sense, we argue that the absence of state apparatuses to enforce sanitation law and prosecute violators diminishes villagers' social control, which is otherwise well maintained within household waste management practices. This leaves space for further research.

\subsection{Civil Society and Political Technology}

Exercising the "conduct of conduct," as posited by Li (2007), in the context of Ala Ajagbusi, NURTW is exercising the "conduct of conduct" to shape and order the waste management behaviour of the villagers. Applying Li's notion of "conduct of the conduct", we argue that the NURTW Ala unit wants to make changes by stopping villagers from dumping waste in the waterway. We argue that the rationalities of exercising the mentality of government are: (1) to stop the villagers from trashing the waterway; (2) to reduce the existing waste in the waterway; and (3) to avoid flash flooding and the possibility of contracting diseases. In light of the rationalities, the union deploys programmes that resemble technologies of government to order the behaviour of the subjects without force, as posited by Michel Foucault. The delegation of each member of the union to be at the carpark before dawn, the financial contribution towards burning of waste in the waterway, and the delegation of members on the market day to ensure compliance of order among the marketers are all NURTW programmes. Those programmes represent political technologies used to shape the waste disposal behaviour of the villagers. The NURTW waste management programmes in the context of Ala Ajagbusi are similar to a case involving Coca-Cola and the issue of child obesity (Powell and Gard 2015). As argued by the authors, Coca-Cola's programmes are akin to government technologies intended to make a change in children's lifestyle. Neither teachers nor children have control over the lifestyle and behaviour needed to reduce child obesity. This makes us understand that behaviour change is a practice of government (Dilley 2012).

The change of waste dumping site from the waterway to under the power line is neither directed nor encouraged, but is being achieved through the deployment of political technologies by the NURTW in an indirect way. To this end, we argue that it is not the state alone, but several actors or groups of actors who want to make a change who can shape or order the behaviour of the second or third party indirectly without the use of force, as opined by Li (2007). This position is similar to that of Michel Foucault when he posited that individual behaviour could be steered or directed in an indirect way. Furthermore, the "conduct of conduct" in the context of Ala NURTW is the deployment of members to the waterway before dawn to produce subjectivities; the conduct of the villagers regardless of their sovereignty.

\subsection{Land Owners and Political Technology}

Conflict between the landowners and villagers as a result of villagers' indiscriminate waste disposal practices on their lands provoked landowners to use force through the technologies of perimeter fencing. The objective is to prevent villagers from trashing the land with waste. This is similar to rationalities of government as posited by Foucault. The rationalities of the landowners are to get rid of waste on their land and stop villagers from trashing their land. The bamboo perimeter fencing and knotted red fabric are synonymous with political technologies devised in order to achieve the rationalities. The knotted red fabric signals that anyone who trashes the land would be attacked diabolically. The mechanism deployed by the landowners is similar to Michel Foucault's notion of a political mechanism that directs the behaviour of actors without force. In this context, the landowners erected bamboo as perimeter fencing with knotted red fabric without having personal contact with the villagers, which can be seen as an example of the use of force over distance by the landowners. The use of force/control over distance through the landowners' technologies of bamboo and fabric perimeter fencing is similar to the governmentality in the Coca-Cola case (Powell and Gard 2015). 
The need to stem the rise of obesity among children positions Coca-Cola to occupy school space through pedagogical programmes such as "step with it Singapore!" and "energy balance 101" in the USA. These programmes, as argued by the authors, represent a use of control/force over distance on the body, lives and thought of children, despite their sovereignty. Stemming the rise of obesity is the rationality of the government in this case and pedagogical programmes are technologies of government used by Coca-Cola. Therefore, there is a convergence of rationality and technology that brings about governmentality. Furthermore, Dilley (2012) argues that Defra in the UK (Department of Environment, Food, and Rural Affairs) attempted to govern over distance by inciting particular modes of conduct by aligning with, fostering and working through people's subjectivity and capacity for self-government through third sector technology. This is to say Defra, a government organ, partners with a community group, a third sector, in order to encourage individual proenvironmental behaviour in the community, such as energy saving awareness meetings, quizzes, etc. Then, the travel wisely concept encourages members of the community to walk or cycle when they are travelling short distances. All these are attempts to govern over distance, while Defra is governing individuals' behaviour through third sector technology.

The bamboo perimeter fencing indicates the boundary of the land, while the knotted red fabric symbolizes diabolic threat against anyone who may trash the land. In an African context, the spiritual threat is handled with care. This is because everyone knows the great impact such an attack could have on their lives. In this context the strategy of the bamboo and red fabric fence produces new waste disposal behaviour without compulsion or direction. The behaviour is directed in an indirect way, as posited by Michel Foucault: one set of behaviour could be encouraged or steered without direct force, but instead by force over distance. In this case, the landowners do not want the villagers to turn their land into a dumping site, and do not provide alternative dumping sites. To this end, villagers choose new dumping sites where it seems to them that it would not be a point of conflict with anyone, i.e., under the power line. In this context, the waste disposal behaviour remains dumping, but villagers are directed indirectly through the technologies of bamboo and red fabric fencing to change their dumping site from private space to public space.

\section{Limitations}

The theoretical framework that this research adopts has been carefully chosen and adapted to answer the research question. In the end, the arguments presented in this research answered the research question in a concise way and it is easy to follow the arguments presented herein. The number of informants in this study is relatively small compared to the entire population of the village, which might suggest the need for further investigation. However, importantly, the results of this study provide relevant information and understanding of the waste handling situation in Ala Ajagbusi and are similar to other previous waste management studies in Nigeria. In addition, the first author was unable to observe villagers' everyday sweeping behaviour before dawn due to the impossibility of spending a night in the study area because the village is not connected to the national electricity grid, does not have safe drinking water sources and the houses lack toilets.

\section{Conclusions}

How the members of households in Ala Ajagbusi village handle waste is addressed. The empirical findings show that the handling of the waste in the village is done at the intra- and inter-household level without any engagement with local or state government. The villagers' engagement is more robust at the intra-household level when compared with the inter-household level. The villagers generate waste on a daily basis, gather waste and dump it in an illegal site. With respect to the theoretical framework adopted in this research, and with the aim of linking waste management handling to social theory, the members of the households adopt moral codes and social control as guiding principles to play into the informal rules of waste management practices in Ala Ajagbusi. The members of the households rotate the sweeping of the households on a weekly basis, which is strictly adhered to as a result of the 
morality involved. The argument of moral code is being brought forward because there are no local officers to enforce sanitation laws; if there were state or local administration officers on the ground to enforce sanitation laws, one could argue that the fear of arrest motivates sweeping behaviour among the villagers. The moral codes that are adhered to within the households fade away when the waste disposal is indiscriminately done by the villagers beyond the household, due to the nonexistence of a waste management structure in the village. This has been attributed to the land dispute crisis, which hinders the operation of the local government's sanitation officers. This is to say, there is a nexus between conflict and development. Empirically, we understand that the moral codes and the fear of contracting diseases motivate sweeping behaviour among the villagers, as well as actions by the landowners, NURTW and MWA, who each devise technologies that shape the waste disposal behaviours of the villagers. Essentially, the paper provides important aspects of the waste management practices that can be used in all Sub-Saharan regions of Africa. This is to say that, as narrated by the informants, the strict implementation of monthly sanitation programme will change the narrative of waste management practices of the villagers, and entry of private investors in the areas of provisioning of waste bin, evacuation trucks, and landfill site will reshape the waste management behaviour of the villagers to a proper one.

The research identifies further research opportunities to: (1) understand the disparity in exercising moral codes in a household and beyond a household; and (2) investigate the readiness of villagers to pay for waste management services provided by private investors in the absence of waste management structures provided by the government.

Author Contributions: The research article was adapted from the Master's thesis submitted by S.A.A. to the Department of Urban and Rural Development, SLU, Sweden. The conceptualization, data collection, and writing processes were carried out by S.A.A. O.B. guided and supervised the whole process of the master thesis.

Acknowledgments: First author thank Swedish University of Agricultural Sciences (SLU) management for the scholarship to pursue a Master's by research in Rural Development and thank Fayi Alghamdi for several motivating discussions. We thank Kjell Hansen for his valuable comments and critique. We also appreciate both Muslim Amin and Caitlin McCormack for their efforts and time with a grammar and spelling check.

Conflicts of Interest: The authors declare no conflicts of interest.

\section{References}

Abila, Beatrice, and Jussi Kantola. 2013. Municipal Solid Waste Management Problems in Nigeria: Evolving Knowledge Management Solution. World Academy of Science, Engineering and Technology International Journal of Environmental, Chemical, Ecological, Geological and Geophysical Engineering 7: 303-8.

Adogu, Prosper Obunikem Uchechukwu, Kenechi Anderson Uwakwe, Nonye Bibiana Egenti, A. P. Okwuoha, and Ihuoma B. Nkwocha. 2015. Assessment of Waste Management Practices among Residents of Owerri Municipal Imo State Nigeria. Journal of Environmental Protection 6: 446-56. [CrossRef]

Ala Ajagbusi Climate Data. 2017. Available online: https://en.climatedata.org/location/362840 (accessed on 5 May 2017).

Amos, Karin. 2010. Governance and Governmentality: Relation and Relevance of two Prominent Social Scientific Concepts for Comparative Education. Educação e Pesquisa 36: 23-38. [CrossRef]

Bello, Ibrahim Adebayo, Muhamad Norshafiq bin Ismail, and Nassereldeen A. Kabbashi. 2016. Solid Waste Management in Africa: A Review. International Journal of Waste Resources 6: 201-4.

Boateng, Simon, Prince Amoako, Divine Odame Appiah, Adjoa Afriyie Poku, and Emmanuel Kofi Garsonu. 2016. Comparative Analysis of Households Solid Waste Management in Rural and Urban Ghana. Journal of Environmental and Public Health 2016. [CrossRef] [PubMed]

Burgess, Robert G. 1984. In the Field: An Introduction to Field Research. London: Allen and Unwin.

Creswell, John W. 2009. Research Design: Qualitative, Quantitative, and Mixed Methods Approaches, 3rd ed. London: SAGE Publications, Inc.

Creswell, John W. 2014. Research Design: Qualitative, Quantitative, and Mixed Methods Approaches. Thousand Oaks: SAGE Publications. 
Dallegrave, Daniela, and Ricardo Burg Ceccim. 2013. Expression of the Governmentality Process in Health Care Residencies. Interface-Comunicação, Saúde, Educação 20: 377-88. [CrossRef]

Dean, Mitchell. 2010. Governmentality: Power and Rule in Modern Society, 2nd ed. London: SAGE.

Dilley, Luke Tobias Martin. 2012. Governing Pro-Environmental Behaviour Change: A Governmentality Approach. Ph.D. thesis, Newcastle University, Newcastle upon Tyne, UK.

Foucault, Michel. 1991. The Foucault Effect: Studies in Governmentality: With Two Lectures by and an Interview with Michel Foucault. Edited by Graham Burchell, Colin Gordon and Peter Miller. Chicago: The University of Chicago Press.

Hanifzadeh, Mohammadmatin, Zahra Nabati, Pairote Longka, Pomthong Malakul, Defne Apul, and Dong-Shik Kim. 2017. Life cycle assessment of superheated steam drying technology as a novel cow manure management method. Journal of Environmental Management 199: 83-90. [CrossRef] [PubMed]

Hanifzadeh, Mohammadmatin, Mohammad-Hossein Sarrafzadeh, Zahra Nabati, Omid Tavakoli, and Hamid Feyzizarnagh. 2018. The technical, economic and energy assessment of an alternative strategy for mass production of biomass and lipid from microalgae. Journal of Environmental Chemical Engineering 6: 866-73. [CrossRef]

Ifegbesan, Ayodeji Peter. 2010. Solid Waste Management Practices in Two Southwest State, Nigeria: Household Perspective. Available online: http:/ / www.docplayer.net/21119992-Solid-waste-management-practicesin-two-southwest-states-nigeria-households-perspectiv.html (accessed on 21 November 2016).

Inglis, David, and Christopher Thorpe. 2012. An Invitation to Social Theory. Cambridge: Polity.

Johl, Satirenjit Kaur, and Sumathi Renganathan. 2010. Strategies for Gaining Access in Doing Fieldwork: Reflection of two Researchers. The Electronic Journal of Business Research Methods 8: 42-50.

Kadfak, Alin. 2011. An Analysis of the Social Relations in Waste Management: Two Case Studies on Somanya and Agormanya in Ghana. Master's thesis, Uppsala University, Uppsala, Sweden.

Lemke, Thomas. 2000. Foucault, Governmentality, and Critique. Paper presented at Rethink Marxism Conference, Amherst, MA, USA, September 21-24.

Li, Tania Murray. 2007. The Will to Improve: Governmentality, Development, and the Practice of Politics. Durham: Duke University Press.

Mansur, Aminu. 2015. An Analysis of Solid Waste Generation and Disposal in Dutse Sahelian Zone of Jigawa State, Nigeria. International Journal of Agriculture and Crop Sciences 8: 81.

Mason, Jennifer. 2002. Qualitative Researching, 2nd ed. London, Thousand Oaks and New Delhi: SAGE.

Miller, Peter, and Nikolas Rose. 2008. Governing the Present. Cambridge: Polity.

Monney, Isaac, Benjamin Makimula Tiimub, and Henry Chendire Bagah. 2013. Characteristics and management of household solid waste in urban areas in Ghana: The case of WA. Civil and Environmental Research 3: 10-21.

Research and Enterprise Services, Newcastle University, Newcastle upon Tyne NE1 7RU, United Kingdom. Email Webmaster (mailto:lynn.hedley@ncl.ac.uk) Last Updated 29 September 2015. (c) 2018 Newcastle University (http://www.ncl.ac.uk/info/legal/). Available online: http:/ / www.ncl.ac.uk/res/research/ ethics_governance/ethics_governance_toolkit/human/gatekeeper/index.htm (accessed on 1 April 2018).

Ogwueleka, Toochukwu Chibueze. 2013. Survey of household waste composition and quantities in Abuja, Nigeria. Resources Conservation and Recycling 77: 52-60. [CrossRef]

Oluwadare, Olamiju Isaac, and Olujimi Julius. 2011. Regional analysis of locations of public educational facilities in Nigeria: The Akure region experience. Journal of Geography and Regional Planning 4: 428-42.

Powell, Darren, and Michael Gard. 2015. The governmentality of childhood obesity: Coca-Cola, public health and primary schools. Discourse: Studies in the Cultural Politics of Education 36: 854-67. [CrossRef]

Silverman, David. 2015. Interpreting Qualitative Data. Thousand Oaks: SAGE Publications.

Solomon, Aisa Oberlin. 2011. The Role of Households in Solid Waste Management in East Africa Capital Cities. Ph.D. thesis, Wageningen University, Wageningen, The Netherlands.

(C) 2018 by the authors. Licensee MDPI, Basel, Switzerland. This article is an open access article distributed under the terms and conditions of the Creative Commons Attribution (CC BY) license (http://creativecommons.org/licenses/by/4.0/). 